\title{
SUATU TINJAUAN TENTANG SISTEM AKUNTANSI PENERIMAAN KAS PADA BUMIDA BUMIPUTERA PEMATANGSIANTAR
}

\author{
Oleh: \\ Rosma Simangunsong \\ (Dosen FKIP Universitas HKBP Nommensen Medan)
}

\begin{abstract}
Cash receiving transaction is financial transaction that create the influence of cash. The are some goals in cash receving system, such as: to prepare and to make the reality data, to keep the asset of organization and the documents of the company to influence the efficiency cash receiving. Which be related with the employee, to finish some cases in a company. There are two data analysis methods in this research: descriptive and comperative methods. A descriptive method is a method that analize data systematically, actual and real about the factors, characteristic and the relation between the aspects which be analized and comperative methods. That differed some theories and some facts that be received by observation in some process to take the conclusion. The conclution of the research is the key that prove cash receiving system of Bumida Bumiputera Pematangsiantar. It shows that cash receiving system is cash sales. The cash is done by the company in paying the premium assurance and the assurance is given to the assurance holder
\end{abstract}

Keywords: transaction, cash, sales, asset, assurance.

\section{Latar Belakang}

Kas dalam perusahaan merupakan aktiva yang paling likuid, karena hampir setiap transaksi yang dilakukan oleh bagian yang berwenang atau yang terkait dalam perusahaan maupun dengan pihak luar akan mempengaruhi sebagian besar kas. Selain itu kas bersifat mudah dipindahtangankan dan dimanipulasi, sehingga kas merupakan aktiva yang rawan untuk dicuri. Keadaan ini akan mendorong perusahaan untuk melakukan penataan pada sistem akuntansi penerimaan kas yang meliputi beberapa aspek yang saling berkaitan. Penyimpangan yang dilakukan biasanya berasal dari hasil penjualan tunai pelunasan piutang dari pelanggan dan sebagainya. Karena jenis penerimaan kas yang diterima cukup besar maka perusahaan perlu menerapkan suatu sistem agar peneriman kas tersebut dapat terkontrol dengan baik.

Sebagaimana pada Bumida Bumiputera Pematangsiantar merupakan suatu instansi atau perusahaan yang bergerak di bidang jasa asuransi. Sumber penerimaan kas pada Bumida Bumiputera Pematangsiantar yaitu diperoleh dari penjualan tunai. Dalam penjualan tunai pembeli diharuskan terlebih dahulu menyetorkan sejumlah uang secara langsung. Semua transaksi yang berkaitan dengan penerimaan kas harus disetorkan ke bank yang telah ditentukan oleh perusahaan pada hari itu juga atau hari berikutnya, dan harus melibatkan bagian-bagian dalam perusahaan agar transaksi penerimaan kas yang dihasilkan sesuai dengan hasil laporan keuangan. 


\section{Rumusan Masalah}

Berdasarkan latar belakang di atas maka penulis merumuskan dalam bentuk pernyataan sebagai berikut: "Bagaimana pelaksanaan sistem penerimaan kas pada Bumida Bumi Putera Pematangsiantar".

\section{Kerangka Pemikiran}

Menurut Mulyadi (2001:3): "Sistem akuntansi adalah organisasi formulir catatan dan laporan yang dikoordinasi sedemikian rupa untuk menyediakan informasi keuangan yang dibutuhkan oleh manajemen guna memudahkan pengelolaan perusahaan". Selanjutnya Zaki Baridwan dalam bukunya sistem akuntansi (2004:4) menyatakan bahwa, "sistem akuntansi adalah formulir-formulir, catatan-catatan, prosedur-prosedur, dan alat-alat yang digunakan untuk mengelolah data mengenai usaha suatu kesatuan ekonomis dengan tujuan untuk menghasilkan umpan baik dalam bentuk laporan-laporan yang diperlukan manajemen untuk mengawasi usahanya, dan bagi pihak-pihak lain yang berkepentingan seperti pemegang saham, kreditur dan lembaga-lembaga pemerintah untuk menilai hasil operasi.

Seterusnya Carl S. Warren (2008:206) menyatakan bahwa, "sistem akuntansi adalah metode dan prosedur untuk mengumpulkan, mengklasifikasikan, mengikhtisarkan, dan melaporkan informasi dan keuangan sebuah perusahaan". Dari beberapa defenisi di atas dapat disimpulkan bahwa sistem akuntansi adalah susunan berbagai catatan, prosedur-prosedur dan teknik yang diperlukan untuk mengumpulkan data dan mengelolanya sehingga mendapat bahan informasi yang saling berhubungan untuk mencapai tujuan.

Jerry J. Weygandt (2007:462) menyatakan, "Kas adalah terdiri atas koin, uang kertas, money order (wesel atau kiriman uang melalui pengiriman yang lazim berbentuk daftar bank atau cek bank), dan uang tunai ditangan atau simpanan di bank atau semacam deposito". Sedangkan Smith Skousen (2000:242) menyatakan, "Kas adalah merupakan aktiva lancar yang paling likuid (cair) dan terdiri dari pos-pos yang berlaku sebagai alat tukar dan memberikan dasar bagi pengukuran akuntansi".

Penerimaan kas perusahaan berasal dari 2 sumber utama yaitu: penerimaan kas dari penjualan tunai dan penerimaan kas dari piutang. Penjualan tunai dilaksanakan oleh perusahaan dengan cara mewajibkan pembeli melakukan pembayaran, harga barang lebih dahulu sebelum barang diserahkan oleh perusahaan-perusahaan kepada pembeli. Setelah uang diterima oleh perusahaan, barang kemudian diserahkan kepada pembeli dan transaksi penjualan kemudian dicatat oleh perusahaan. Penerimaan kas dari penjualan tunai biasanya ditangani oleh kasir dengan menggunakan peralatan kas register.

Seterusnya Jerry J. Weygandt (2007:268) menyatakan bahwa, "pendapatan penjualan dihasilkan ketika barang dialihkan dari penjual ke pembeli. Pada saat tersebut transaksi penjualan telah selesai, dan harga penjualan telah ditetapkan". Selanjutnya Sigit Winarno dan Suzana Ismaya dalam Kamus Ekonomi (2003:380) menyatakan bahwa, "Penjualan tunai adalah menyatakan salah satu nama rekening untuk mencatat pendapatan yang besar dari berbagai transaksi yang dilakukan perusahaan" Sistem penerimaan kas dari penjualan tunai dibagi menjadi 3 prosedur, yaitu:
(1) Prosedur penerimaan kas dari over the counter sale, dalam penjualan tunai ini, pembeli datang ke perusahaan melakukan pemilihan barang atau produk yang akan di beli, melakukan pembayaran ke kasir, dan kemudian menerima barang yang di beli. Menurut Mulyadi (2001: 456) prosedur yang dilakukan dalam proses penerimaan kas dari over the counter sales adalah: (a) pembelian memesan barang langsung kepada wiraniaga (sales person) dibagian penjualan; (b) kas menerima pembayaran dari pembeli, yang dapat berupa uang tunai cek pribadi (personal check), atau kartu kredit; (c) Bagian 
penjualan memerintahkan bagian pengiriman untuk menyerahkan barang kepada pembeli; (d) Bagian pengiriman menyerahkan barang kepada pembeli; (e) Bagian kas menyetorkan kas yang diterima ke bank; (f) Bagian akuntansi mencatat pendapatan penjualan dalam bagian jurnal penjualan; (g) Bagian akuntansi mencatat penerimaan kas dari penjualan tunai dalam jurnal penerimaan kas".

Selanjutnya Zaki Baridwan (2004:157), mengatakan bahwa, "Prosedur penerimaan kas melibatkan beberapa bagian dalam perusahaan agar transaksi penerimaan uang tidak terpusat pada satu bagian saja, hal ini perlu agar dapat memenuhi prinsip-prinsip internal control. Bagian-bagian yang terlibat dalam prosedur penerimaan uang adalah bagian surat masuk, kasir, piutang dan bagian pemeriksa intern".

Dari beberapa pendapat di atas dapat disimpulkan bahwa kas yang berasal dari register masing-masing kasir dihitung dan dibukukan dalam bentuk memorandum. Kas tesebut dimasukan ke lemari penyimpanan di Departemen kasir sehingga disetor ke Bank. Pengawas menyampaikan struk atau pita register dari kasir bersangkutan ke Departemen Akuntansi, dimana hal ini digunakan sebagai dasar untuk mencatat transaksi pada hari tersebut.

(2) Prosedur penerimaan kas dari COD Sales (Cash on Deliver), menurut Carl S. Warren, dkk. (2006:365), Prosedur penerimaan kas dari COD sales adalah: (a) Pelanggan mengirimkankan pembayaran melalui pos, yang berupa cek dan wesel atau daftar bank. Perusahaan merancang faktur sedemikian rupa sehingga pelanggan / pembeli mengembalikan sobekan dari faktur yang disebut slip pembayaran; (b) Karyawan yang membuka surat masuk harus terlebih dahulu membandingkan jumlah kas yang diterima dengan jumlah yang diperlihatkan pada slip pembayaran; (c) Bila pelanggan tidak mengembalikan slip pembayaran, maka karyawan harus menyiapkannya. Sebagaimana halnya dengan register kas, slip tersebut berfungsi sebagai catatan atas kas yang diterima; /(d) Karyawan yang membuka kiriman pos lazimnya juga memberi cap semua cek dan wesel dengan tanda "tidak diuangkan" sehingga cek dan kiriman uang hanya boleh dimasukkan ke rekening bank perusahaan tersebut; (e) Semua kas yang diterima melalui pos disampaikan ke Departemen kasir. Karyawan Departeman tersebut akan menggabungkannya dengan penerimaan dan penjualan tunai dan menyiapkan formulir setoran ke bank; (f) Slip pembayaran dan hasil penjumlahannya disampaikan ke Departemen Akuntansi; (g) Petugas akuntansi menyiapkan catatan atas transaksi tersebut dan memposkannya ke akun-akun pelanggan; (h) Kas disetorkan ke bank, bank lazimnya membubuhkan cap atau cetakan komputer pada salinan formulir setoran. Tanda terima dari bank ini dikembalikan ke departemen akuntansi dimana karyawan akan membandingkannya dengan jumlah total yang harus disetorkan.

Seterusnya H. Djauhari Ashar (2007:30), mengatakan prosedur penerimaan dari COD sales adalah: "Pada waktu penyerahan barang yang akan dikirim ke yang berkaitan dangan waktu/tanggal pengapalan barang dengan menetapkan negara asal barang, menetapkan pelabuhan muat, serta pelabuhan tujuan.

Dari pendapat di atas dapat disimpulkan bahwa COD sales merupakan sarana untuk memperluas daerah pemasaran dan untuk memberikan jaminan penyerahan barang bagi pembeli dan jaminan penerimaan kas bagi perusahaan penjual. Pemisahan tugas diantara departemen akuntansi yang membukukan kas, merupakan pengendalian
preventif. (3) Prosedur penerimaan kas dari Credit Card Sales, credit card merupakaan salah satu pembayaran bagi pembeli dan sarana penagihan bagi penjual yang memberikan kemudahan baik bagi pembeli maupun bagi penjual. Dalam Over-the-counter sales maupun dalam penjualan yang pengiriman barangnya dilaksanakan melalui jasa pos atau angkutan umum. 
Menurut Mulyadi (2001:459) menyatakan bahwa, Dalam Over-the-caunter sale, pembeli datang ke perusahaan, melakukan pemilihan barang atau produk yang akan dibeli, melakukan pembayaran ke kasir dengan menggunakan kartu kredit. Dalam penjualan tunai yang melibatkan pos atau perusahaan akuntansi umum, pembeli tidak perlu datang ke perusahaan. Pembeli memberikan persetujuan tertulis pengguna kartu kredit dan pembayaran harga barang, sehingga memungkinkan perusahaan penjual melakukan penagihan kepada bank atau perusahaan penerbit kartu kredit".

Selanjutnya Carl S. Warren, dkk (2006:366) mengatakan bahwa: Prosedur penerimaan kas dari credit card sales adalah: (a) Voucher disiapkan oleh Departemen Akuntansi setelah semua dokumen pendukung yang diperlukan diterima; (b) Dalam menyiapkan voucher, petugas utang usaha meneliti kuantitas, harga, dan keakuratan laporan pada dokumen pendukung. Hal ini memberi jaminan bahwa pembayaran dilakukan untuk barang yang dipesan dan diterima sebagaimana mestiny; (c) Setelah voucher disiapkan, voucher tersebut dan dokumen pendukung disampaikan kepasa pejabat berwewenang untuk mendapat persetujuan; (d) Kemudian voucher tersebut diarsipkan pada arsip voucher yang belum dibayar berdasarkan tanggal jatuh tempo sehingga semua diskon pembelian yang tersedia dapat diambil; (e) Pada tanggal jatuh tempo, voucher dipindahkan dari arsip voucher yang belum dibayar. Pembayaran atas voucher tersebut dibukukan sebagaimana halnya dengan pembayaran utang usaha; (f) Setelah dibayar voucher dicap 'lunas' pada biasanya diarsip berdasarkan nomor urut pada arsip voucher yang sudah dibayar. Lalu diperiksa oleh karyawan".

Dari pendapat di atas dapat disimpulkan bahwa credit card bukan merupakaan suatu tipe penjualan, namun merupakan salah satu pembayaran. Pembayaran ini cukup aman untuk kedua belah pihak, karena adanya pihak ketiga yang menjamin dan mengamankan pembayarannya.

Dalam sistem pencatatan penerimaan kas dari penjualan tunai dibutuhkan dokumen-dokumen pendukung. Dokumen-dokumen tersebut adalah (Mulyadi, 2001:463): (a) Faktur penjualan tunai, dokumen yang digunakan untuk merekam berbagai informasi yang diperlukan oleh manajemen mengenai transaksi penjualan tunai; (b) Pita register kas (cash regisrer tape), dokumen ini dihasilkan oleh fungsi kas dengan cara mengoprasikan mesin register kas (cash register tape); (c) Credit Card Sales Slip, dokumen ini dicetak oleh credit card center bank yang menerbitkan kartu kredit dan diserahkan kepada perusahaan yang menjadi anggota katu kredit; (e) Bill of lading, dokumen ini menyerahkan barang dari perusahaan penjualan barang kepada perusahaan angkutan umum; (e) Bukti setor bank, dokumen dibuat oleh fungsi kas sebagai bukti penyetoran kas ke bank; (f) Faktur penjualan COD, dokumen ini digunakan untuk menerapkan penjualan COD; $(\mathrm{g})$ Rekap harga pokok penjualan, dokumen ini digunakan oleh fungsi akuntansi untuk meringkas harga pokok produk yang dijual selama satu periode.

Seterusnya Soemarso S.R. dalam bukunya Suatu Pengantar Bisnis (2002:172) menyatakan bahwa:"Buku penerimaan kas yang digunakan dalam sistem akuntansi penerimaan kas dari penjualan tunai adalah aktur penjualan tunai dan kartu piutang dagang. Sedangkan menurut Djauhari Ahsjar (2007:81) dokumen yang digunakan adalah: (a) Bill of lading, salah satu dokumen yang negotible dan berharga dalam handling /negosiasi transaksi ekspor; (b) Commersial invoice, salah satu dokumen penting yang memuat perincian harga-harga barang yang dikeluarkan oleh pihak perusahan penjual atas transaksi tertentu dengan pihak pembeli." Berdasarkan kutipan di atas dapat disimpulkan sistem dokumen yang digunakan dalam sistem akuntansi penerimaan kas dari penjualan tunai adalah: faktur penjualan 
tunai, pita register kas, credit card sales slip, bill of landing, faktur penjualan COD, bukti setoran bank, rekap harga pokok penjualan, dan kartu piutang dagang.

Selain dokumen-dokumen di atas ada beberapa fungsi-fungsi yang terkait dalam sistem akuntansi penerimaan kas dari penjualan tunai adalah: fungsi penjualan, fungsi kas, fungsi gudang, fungsi pengiriman, dan fungsi akuntansi.

Catatan akuntansi yang digunakan dalam sistem akuntansi penerimaan kas dari penjualan tunai adalah: a.) jurnal penjualan digunakan oleh fungsi akuntansi untuk mencatat dan meringkas data penjualan, b.) jurnal penerimaan kas digunakan oleh fungsi akuntansi untuk mencatat penerimaan kas dari berbagai sumber diantaranya penjualan tunai, dan c.) jurnal umum digunakan oleh fungsi akuntansi untuk mencatat harga pokok produk yang dijual.

Ada beberapa prosedur yang harus dilakukan dalam proses penerimaan kas dari penjualan tunai yaitu prosedur order penjualan, prosedur penerimaan kas, prosedur penerimaan barang, prosedur pencatatan tunai, dan prosedur penyetoran uang ke bank" (Mulyadi, 2001:469). Sedangkan menurut Soemita (2000:72) prosedur yang dilakukan adalah: (a) Prosedur penjualan, semua penjualan kontan harus dicatat dalam register kas (cash register), yang mengetik jumlah penjualan di atas tape pita penerimaan yang dicatat dari kertas, dan uangnya harus disimpan dilakukan dalam laci register kas; (b) bagian kas, bagian kas yang menghitung uang kas yang ada dalam tiap register kas pada akair hari dan mengambil semua uang dari laci register kas kecuali uang kecil untuk dana penukaran; (c) Penerimaan-penerimaan kas itu kemudian diserahkan kepada karyawan yang diberi tugas untuk menyetorkan uang itu ke bank; (d) Prosedur bagian akunting untuk piutang-piutang. Catatan penerimaan uang dari para pelanggan digunakan untuk mengkredit kartu-kartu piutang dan perkiraan pengendalian piutang-piutang di buku besar".

Dari beberapa pendapat di atas dapat disimpulkan bahwa terdapat pemisahan tugas antara yang menyimpan, yang menerima dan yang mencatat penerimaan uang dan setiap penerimaan uang langsung disetor ke Bank sebagaimana adannya. Uang yang diterima bisa berbentuk uang tunai, baik logam maupun uang kertas, cek, bank drafts, dan lain-lain.

Sumber penerimaan kas suatu perusahaan manufaktur biasanya berasal dari pelunasan-pelunasan piutang dari debitur karena sebagai produk perusahaan tersebut dijual melalui penjualan kredit.

Menurut C. Rollin Niswanger (2000:165) dalam bukunya prinsip-prinsip akuntansi menyatakan bahwa, "Piutang meliputi semua klaim dalam bentuk uang terhadap perorangan, organisasi atau debitur lainnya". Selanjutnya Soemarso (2004:365) menyatakan bahwa, "Piutang adalah kebiasaan bagi perusahaan untuk memberikan kelonggaran-kelonggaran kepada langganan-langganannya pada waktu melakukan penjualan. Kelonggaran-kelonggaran yang diberikan biasanya dalam bentuk memperbolehkan kelonggaran membayar kemudian atas penjualan barang/jasa yang dilakukan".

Seterusnya menurut Smith Skousen dalam bukunya Intermediate Accounting (2002:03) menyatakan, "Piutang ialah hak atau tagihan perusahaan kepada pihak lain yang akan dimintakan pembayarannya atau pelunasannya bilamana telah sampai pada waktunya". Dari beberapa pengertian di atas dapat disimpulkan bahwa piutang adalah hak atau tagihan perusahaan kepada pihak lain yang akan dimintakan pembayarannya atau pelunasannya bilamana telah sampai pada waktunya.

Dalam sistem pencatatan penerimaan kas dari piutang dibutuhkan dokumendokumen pendukung. Dokumen-dokumen tersebut adalah: surat pemberitahuan, daftar surat pemberitahuan, bukti setoran bank, dan kuitansi. Menurut Hendi Somantri 
(2004:109) menyatakan bahwa: "Dokumen transaksi yang menjadi sumber pendapatan dalam sistem kas dari piutang adalah faktur penjualan, bukti penerimaan kas, memo kredit, dan bukti memorial. Sedangkan menurut Soemarso S.R. (2004:166), dokumen transaksi dalam sistem penerimaan kas dari piutang adalah faktur penjualan dalah bukti transaksi penjualan dan kartu piutang.

Sedangkan fungsi yang terkait dalam sistem penerimaan kas dari piutang adalah: fungsi sekretariat, fungsi penagihan, fungsi kas, fungsi akuntansi, dan fungsi pemeriksaan intern. Selain catatatan-catatan di atas ada beberapa prosedur yang dilaksanakan dalam proses penerimaan kas dari piutang. Prosedur tersebut yaitu prosedur penerimaan kas dari piutang melalui penagihan dari perusahaan.

Semua penerimaan kas dari debitur harus dalam bentuk cek atas nama atau giro bilyet. Penerimaan kas dari piutang melalui penagihan perusahaan dilaksanakan dengan prosedur sebagai berikut: (1) Bagian piutang memberikan daftar piutang yang sudah saatnya ditagih kepada bagian penagih; (2) Bagian penagihan mengirimkan penagihan, yang merupakan karyawan perusahaan untuk melakukan penagihan kepada debitur; (c) Bagian penagihan menerima cek atas nama dan surat pemberitahuan (remmit-tance advice) dari debitur; (d) Bagian penagihan menyerahkan cek kepada bagian kasa; (e) Bagian penagihan menyerahkan surat pemberitahuan kepada bagian piutang untuk kepentingan posting ke dalam kartu piutang; (f) Bagian kas mengirim kuitansi sebagai tanda penerimaan kas kepada debitur; (g) Bagian kas menyetorkan cek ke bank, setelah cek tersebut diperiksa oleh pejabat yang berwewenang; (h) Bank perusahaan melakukan cleaning atas cek tersebut ke bank.

Bagian jurnal mencatat penerimaan kas dari piutang melalui penagihan perusahaan ini dalam jurnal penerimaan kas bukti setor bank, dengan jurnal: Kas

Piutang usaha
Rp. $x x x$

Rp.xxx

\section{Metode Penelitian}

Penulis memilih lokasi di PT. Bumida Bumiputera Pematangsiantar. Pengumpulan data dengan menggunakan observasi tidak langsung dan wawancara yaitu mengadakan dialog langsung, tanya jawab dengan pimpinan PT.Bumida Bumiputera Pematangsiantar dan pejabat yang berwewenang serta narasumber yang lain yang dapat bertanggung jawab terhadap objek yang diteliti. Jenis data yang dikumpulkan peneliti adalah data yang bersifat kualitatif dan kuantitatif. Data kualitatif adalah data yang diperlukan untuk mengadakan analisa masalah dalam penelitian yang tidak dapat diwujudkan dalam jumlah-jumlah satuan tertentu atau tidak dapat dinyatakan dalam satuan angka.

Responden dalam penulisan ini adalah pimpinan dan karyawan yang terkait dengan tugas-tugas pengumpulan, pencatatan, bagian keuangan, pengarsipan, dokumen, dan lain-lain yang berhubungan dengan sistem akuntansi penerimaan kas pada PT.Bumida Bumiputera Pematangsiantar. Teknik pengumpulan data yang digunakan adalah penelitian pustaka (library research) yaitu penelitian berdasarkan studi kepustakaan dimana bahan penelitian diperoleh dari buku-buku yang berhubungan dengan masalah penelitian dan penelitian lapangan (field research) yaitu penelitian dengan mengadakan pengamatan langsung.

Untuk menganalisa data maka dapat dilakukan dengan menggunakan dua metode yaitu: metode deskriptif dan metode komperatif. Metode deskriptif yaitu suatu metode analisis yang digunakan dengan cara menggambarkan secara sistematis, aktual, dan akurat mengenai faktor-faktor, sifat serta hubungan antara fenomena-fenomena yang diselidiki. Metode komperatif yaitu metode analisa dengan cara membandingkan antara 
teori-teori dan fakta yang diperoleh berdasarkan observasi yang dilakukan secara teliti dan terperinci, sehingga dapat menarik kesimpulan atas berbagai fenomena yang diselidiki serta mengajukan beberapa saran atau rekomendasi kepada pihak PT. Bumida Bumiputera Pematangsiantar.

\section{Hasil Penelitian}

\section{Penerimaan Bumida Bumiputera}

1. Asuransi Karyawan adalah: Memberikan perlindungan kecelakaan diri dan kematian selama 24 jam, baik dalam jam kerja maupun diluar hubungan kerja bagi para karyawan.

2. Asuransi Kebakaran adalah: Memberikan perlindungan untuk perlindungan rumah, hotel, kantor, gudang, pabrik, ruko, dan bangunan lain dari kerusakan akibat kebakaran, gempa bumi, badai/topan, ledakan petir, termasuk kerugian akibat kejatuhan pesawat dan tanggung gugat pihak ketiga.

3. Asuransi Kenderaan Bermotor adalah: Memberikan perlindungan kendaraan bermotor atas kerusakan atau kerugian akibat tabrakan/kecelakaan, tergelincir, terperosok, perbuatan jahat. Termasuk juga ganti rugi kerusakan akibat banjir, bencana alam, tanggung jawab hukum.

4. Asuransi Pengangkutan adalah: Memberikan perlindungan atas ganti rugi kerusakan/kerugian atas barang-barang yang diangkut (lewat air, udara, darat) sebagai akibat kecelakaan, tenggelam atau karam, pencurian, kebakaran, bencana alam dan lain-lain.

5. Asuransi Rangka Kapal adalah: Memberikan jaminan ganti rugi terhadap rangka/struktur kapal dari keseluruhan/kerugiaan akibat kecelakaan, tenggelam/karam, pencurian, kebakaran dan lain-lain.

6. Asuransi kecelakaan Diri adalah: Memberikan jaminan penggantian kerugian akibat kecelakaan. Termasuk didalamnya penggantian biaya perawatan di rumah sakit, santunan cacat tetap maupun cacat sementara, santunan meninggal dunia dan lainlain.

7. Asuransi Kesehatan adalah: Memberikan jaminan penggantian terhadap setiap biaya pengobatan dan rawat inap maupun rawat jalan di rumah sakit. Termasuk juga perawatan gigi dan melahirkan.

8. Asuransi Rekayasa adalah: Memberikan jaminan ganti rugi terhadap kerusakan mesinmesin yang tiba-tiba timbul saat pemasangan dan percobaan mesin, penggantian peralatan maupun struktur baja, pencurian, kebakaran, perubahan tekana, tegangan listrik, tanggung jawab hukum terhadap pihak ketiga, dan lain-lain.

9. Asuransi Aneka adalah: Memberikan perlindungan atas berbagai kerugian lain yang mungkin timbul, diantaranya adalah: hole in one, professional liability, (tanggung jawab hukum) uang tunai dalam tempat penyimpanan, uang tunai pada saat pengiriman, tanggung jawab publik, dan kebongkaran.

10. Asuransi Penjaminan adalah: Memberikan penjaminan penggantirugian bagi pemilik proyek akibat kontraktor gagal melaksanakan proyek atau gagal melakukan pemeliharaan atau memperbaiki kerusakan serta bila kontraktor tidak mengembalikan uang muka sesuai kontrak.

\section{Sistem Akuntansi Penerimaan Kas}

Sistem akuntansi yang digunakan perusahaan ini adalah sistem penerimaan kas dari penjualan tunai: (1) Sistem penerimaan kas dari penjualan tunai pada Bumida Bumiputera, penerimaan kas dari penjualan tunai ditangani oleh kasir dan menggunakan peralatan kas register. Penjualan tunai dilaksanakan oleh perusahaan dengan cara 
mewajibkan pembeli melakukan pembayaran harga premi kemudian kwitansi premi diserahkan kepada pembeli asuransi, kemudian uang masuk ke kas. Kas yang diterima perusahaan dari penjualan tunai harus segera di setor ke Bank. Jika kas yang diterima setiap hari dan disetor ke Bank seluruhnya pada hari yang sama, Bank akan mencatat setoran tersebut dalam catatan akuntansinya; (2) Prosedur penerimaan kas, sistem penerimaan kas dari penjualan tunai pada perusahaan Bumida Bumiputera adalah prosedur penerimaan kas dari over the counter sale (Penerimaan kas dari penjualan). Dimana pembeli datang ke perusahaan atau pembeli dapat melakukan pembelian asuransi melalui agen dan melakukan pembayaran ke kasir, kemudian menerima kwitansi pembelian premi asuransi.

\section{Gambar}

Prosedur Penerimaan Kas

Bumida Bumiputera Pematangsiantar

Bagian pengiriman menyerahkan asuransi

kepada pembeli

Pembeli Datang

(4)

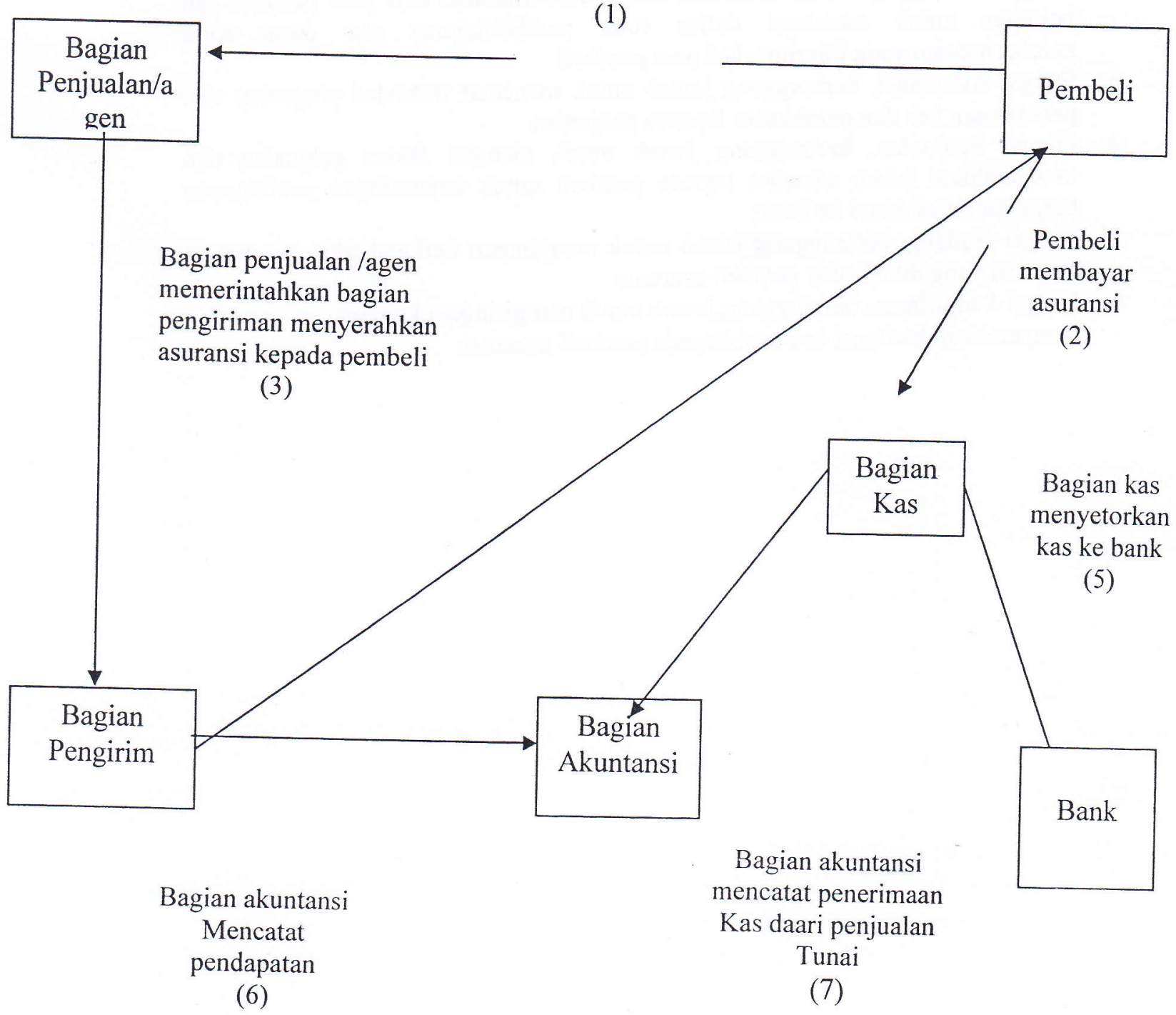


Keterangan Gambar:

1. Pembeli langsung membeli barang ke perusahaan (wiraniaga) di bagian penjualan atau melalui agen.

2. Bagian kassa/kasir menerima pembayaran dari pembeli asuransi, yang berupa uang tunai.

3. Bagian penjualan/agen memerintahkan bagian pengirimaan untuk menyerahkan kwitansi premi asuransi.

4. Bagian pengiriman menyerahkan kwitansi premi kepada pembeli asuransi.

5. Bagian kassa menyetorkan kas yang diterima ke Bank.

6. Bagian akuntansi mencatat pendapatan penjualan asuransi dalam jurnal penjualan.

7. Bagian akuntansi mencatat peneriaan kas dari penjualan tunai dalam penerimaan kas.

\section{Fungsi dan tanggung jawab penerimaan kas} sebagai berikut:

Fungsi dan tanggung jawab penerimaan kas pada Bumida Bumiputera adalah

1. Fungsi Kas, bertanggung jawab untuk menerima uang/kas dari pembeli asuransi

2. Fungsi Sekretaris, untuk menerima surat pemberitahuan dari para pembeli dan bertugas untuk membuat daftar surat pemberitahuan atas dasar surat pemberitahuan yang diterima dari para pembeli

3. Fungsi Akuntansi, bertanggung jawab untuk mencatat transaksi penjualan dari penerimaan kas dan pembuatan laporan penjualan

4. Fungsi Penjualan, bertanggung jawab untuk mengisi faktur penjualan dan menyerahkan faktur tersebut kepada pembeli untuk kepentingan pembayaran harga premi asuransi ke kasir;

5. Fungsi Gudang, bertanggung jawab untuk menyimpan berkas-berkas pembelian asuransi yang dibeli oleh pembeli asuransi

6. Fungsi Pengiriman, bertanggung jawab untuk mengirimkan kwitansi asuransi dan menyerahkan kwitansi asuransi kepada pembeli asuransi. 
Data-data penerimaankKas pada Bumida Bumiputera Pematangsiantar. berikut:

Penerimaan kas pada Bumida Bumiputera tercantum pada data-data sebagai

\section{PT. ASURANSI UMUM BUMIPUTERAMUDA \\ LAPORAN ARUS KAS \\ (CASH FLOWS)}

Per Januari 2005

PEMATANGSIANTAR

\begin{tabular}{|c|c|c|}
\hline & Keterangan & Nilai \\
\hline A & $\begin{array}{l}\text { Saldo Awal } \\
\text { Kas Bank } \\
\text { 1. Kas } \\
\text { 2. Bank } \\
\quad \text { Jumlah Saldo Awal } \\
\text { Arus Kas dari Aktifitas Operasi } \\
\text { Arus Kas dari Aktifitas Operasi } \\
\text { Arus Kas Masuk } \\
\text { 1. Premi } \\
\text { 2. Klaim Reasuransi } \\
\text { 3. Komisi }\end{array}$ & $\begin{array}{r}15,139,188.00 \\
4,110,429.00 \\
19,249,617.00\end{array}$ \\
\hline C & $\begin{array}{l}\text { 4. Droping } \\
\text { Jumlah Arus Kas MAsuk } \\
\qquad \text { Jumlah Arus Kas Masuk } \\
\text { Arus Kas dari Aktifitas Investasi } \\
\text { Arus Kas Masuk } \\
\text { 1. Hasil Investasi Netto } \\
\text { 2. Pencairan Investasi } \\
\text { 3. Penjualan Aktiva Tetap }\end{array}$ & $\begin{array}{l}10,039,000,00 \\
35,371,254,18\end{array}$ \\
\hline D & $\begin{array}{l}\text { 4. Lain-lain } \\
\qquad \text { Jumlah Arus Kas Masuk } \\
\text { Arus Kas dari Aktifitas Pendanaan } \\
\text { Arus Kas Masuk } \\
\text { 1. Pinjaman Subordinasi }\end{array}$ & $\begin{array}{l}18,444,589,00 \\
18,444,589,00\end{array}$ \\
\hline $\mathbf{E}$ & $\begin{array}{l}\text { 2. Setoran Modal } \\
\text { 3. Lain-lain } \\
\qquad \text { Jumlah Arus Kas Masuk } \\
\text { Saldo Akhir Kas- Bank }(\mathrm{A}+\mathrm{B}+\mathrm{C}+\mathrm{D}) \\
\text { 1. Saldo Akhir Kas } \\
\text { 2. Saldo Akhir Bank } \\
\quad \text { Jumlah Saldo Akhir Kas-Bank }\end{array}$ & $\begin{array}{l}0,00 \\
0,00 \\
0,00\end{array}$ \\
\hline
\end{tabular}




\section{PT.ASURANSI UMUM BUMIPUTERAMUDA 1967 \\ LAPORAN ARUS KAS \\ (CASH FLOWS)}

\begin{tabular}{|c|c|c|}
\hline \multicolumn{2}{|c|}{ Per Februari 2005} & PEMATANGSIANTAR \\
\hline & Keterangan & Nilai \\
\hline A & $\begin{array}{l}\text { Saldo Awal Kas Bank } \\
\text { 1. Kas } \\
\text { 2. Bank } \\
\\
\\
\quad \text { Jumlah Saldo Awal }\end{array}$ & $\begin{array}{r}142,950,39 \\
2,661,334,00 \\
2,804,284,39\end{array}$ \\
\hline B & $\begin{array}{l}\text { Arus Kas dari Aktifitas Operasi } \\
\text { Arus Kas Masuk } \\
\text { 1. Premi } \\
\text { 2. Klaim Reasuransi } \\
\text { 3. Komisi } \\
\text { 4. Droping } \\
\quad \text { Jumlah Arus Kas Masuk }\end{array}$ & $\begin{array}{r}29,861,366,48 \\
0,00 \\
0,00 \\
8,715,000,00 \\
38,576,366,48\end{array}$ \\
\hline $\mathrm{C}$ & $\begin{array}{l}\text { Arus Kas dari Aktifitas Investasi } \\
\text { Arus Kas Masuk } \\
\text { 1. Hasil Investasi Netto } \\
\text { 2. Pencairan Investasi } \\
\text { 3. Penjualan Aktiva Tetap } \\
\text { 4. Lain-lain } \\
\quad \text { Jumlah Arus Kas Masuk }\end{array}$ & $\begin{array}{r}0,00 \\
0,00 \\
0,00 \\
10,384,589,00 \\
10,384,589,00\end{array}$ \\
\hline $\mathrm{D}$ & $\begin{array}{l}\text { Arus Kas dari Aktivitas Pendanaan } \\
\text { Arus Kas Masuk } \\
\text { 1. Pinjaman Subordinasi } \\
\text { 2. Setoran Modal } \\
\text { 3. Lain-lain } \\
\quad \text { Jumlah Arus Kas Masuk }\end{array}$ & $\begin{array}{l}0,00 \\
0,00 \\
0,00 \\
0,00\end{array}$ \\
\hline $\mathrm{E}$ & $\begin{array}{l}\text { Saldo Akhir Kas - Bank }(A+B+C+D) \\
\text { 1. Saldo Akhir Kas } \\
\text { 2. Saldo Akhir Bank } \\
\text { Saldo Akhir Kas - Bank }(A+B+C+D)\end{array}$ & \\
\hline
\end{tabular}


PT.ASURANSI UMUM BUMIPUTERAMUDA 1967

LAPORAN ARUS KAS

(CASH FLOWS)

Per Maret 2005

PEMATANGSIANTAR

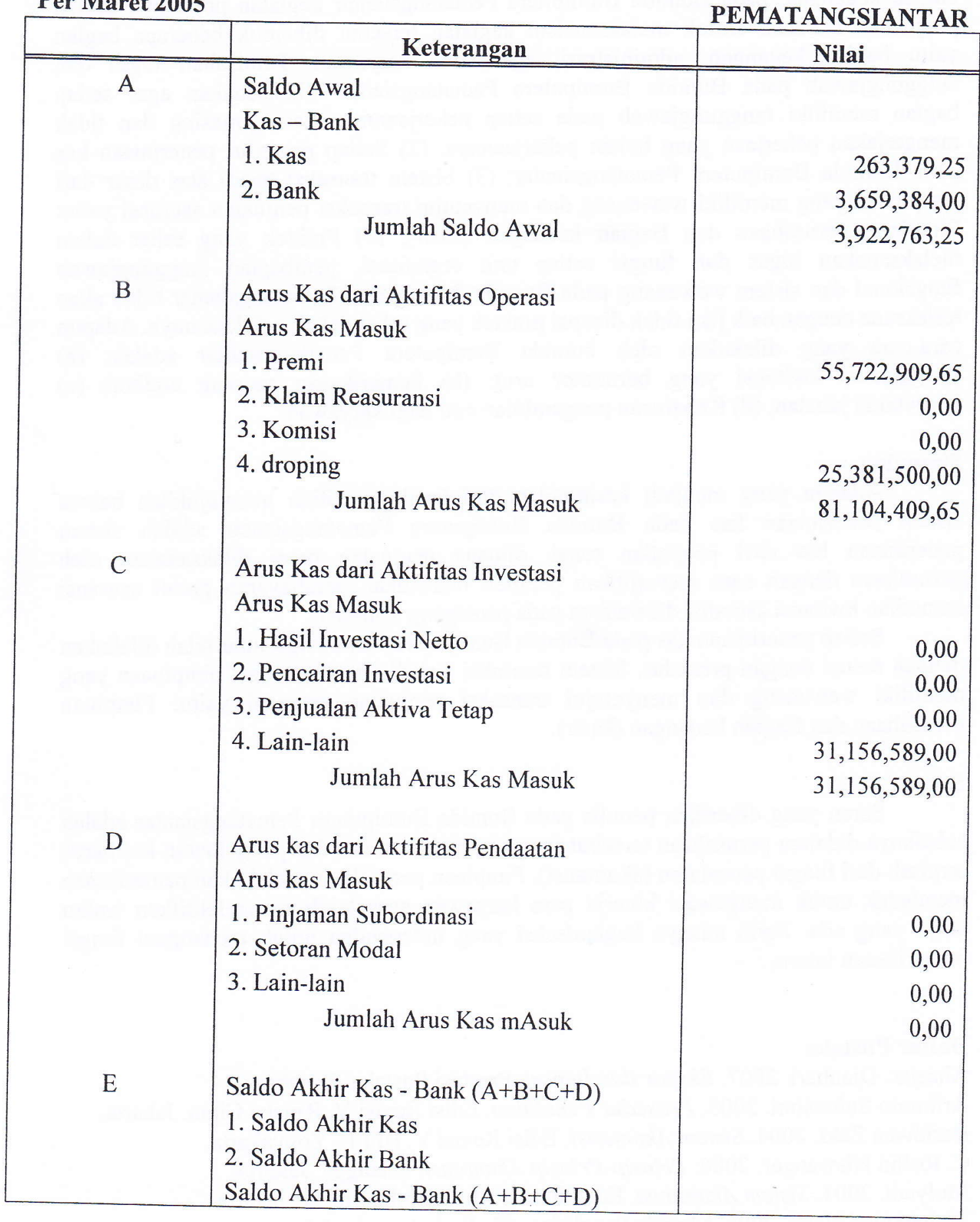




\section{Analisa Data}

Sistem akuntansi penerimaan kas sangatlah penting dalam perusahaan. Demikian pula pada Bumida Bumiputera Pematangsiantar mengadakan sistem penerimaan kas dari penjualan tunai: (1) Stuktur organisasi yang memisahkan tanggung jawab pada setiap bagian keuangan, pada Bumida Bumipitera Pematangsiantar kegiatan pokoknya adalah penjualan asuransi. Untuk melaksanakan kegiatan tersebut dibentuk beberapa bagian yaitu bagian keuangan, administrasi, agen, dan karyawan. Pemisahan tugas dan tanggungjawab pada Bumida Bumiputera Pematangsiantar dilaksanakan agar setiap bagian memiliki tanggungjawab pada setiap pekerjaannya masing-masing dan tidak mengerjakan pekerjaan yang bukan pekerjaannya; (2) Setiap prosedur penerimaan kas pada Bumida Bumiputera Pematangsiantar; (3) Sistem transaksi tejadi atas dasar dari pimpinaan yang memiliki wewenang dan menyetujui transaksi penjualan asuransi yaitu: Pimpinan perusahaan dan Bagian keuangan (kasir); (4) Praktek yang sehat dalam melaksanakan tugas dan fungsi setiap unit organisasi, pembagian tanggungjawab fungsional dan sistem wewenang pada Bumida Bumiputera Pematangsiantar tidak akan terlaksana dengan baik jika tidak dicapai praktek yang sehat dalam pelaksaannya. Adapun cara-cara yang dilakukan oleh bumida Bumiputera Pematangsiantar adalah: (a) Penggunaan kwitansi yang bernomor urut; (b) Pemeriksaan seorang auditor; (c) Perputaran jabatan; (d) Keharusan pengambilan cuti bagi karyawan.

\section{Simpulan}

Adapun yang menjadi kesimpulan dari hasil penelitian menunjukkan bahwa sistem penerimaan kas pada Bumida Bumiputera Pematangsiantar adalah sistem penerimaan kas dari penjualan tunai, dimana penjualan tunai dilaksanakan oleh perusahaan dengan cara mewajibkan pembeli melakukan pembayaran premi asuransi kemudian kwitansi asuransi diserahkan pada pemegang asuransi.

Setiap penerimaan kas pada Bumida Bumiputera Pematangsiantar telah dilakukan dengan sesuai dengan prosedur. Sistem transaksi terjadi atas dasar dari pimpinaan yang memiliki wewenang dan menyetujui transaksi penjualan asuransi yaitu: Pimpinan perusahaan dan Bagian keuangan (kasir).

\section{Saran}

Saran yang diberikan penulis pada Bumida Bumiputera Pematangsiantar adalah sebaiknya didalam perusahaan tersebut fungsi penerimaan kas dan pengeluaran kas harus terpisah dari fungsi pencatatan (akuntansi). Pimpinan perusahaan melakukan pemeriksaan mendadak untuk mengawasi kinerja para karyawan agar lebih mengefektifkan waktu kerja yang ada. Perlu adanya bagian/seksi yang independen untuk menangani fungsi pemeriksaan intern.

\section{Daftar Pustaka}

Ahasjar. Djauhari. 2007. Ekspor dan Import. Prestasi Pustaka. Kotabaru.

Arikunto Suharsimi. 2005. Prosedur Penelitian. Edisi Revisi V. Rineka Cipta. Jakarta.

Baridwan Zaki. 2004. Sistem Akuntansi. Edisi Revisi V. BPFE. Yogyakarta.

C. Rollin Niswanger. 2000. Prinsip-Prinsip Akuntansi. Erlangga. Jakarta.

Mulyadi. 2001. Sistem Akuntansi. Edisi Revisi III. Salemba Empat. Jakarta.

Muhammad Nasir. 2005. Metode Penelitian. Ghalia Indonesia. Jakarta.

Nasution S. 2009. Metode Research. Bumi Aksara. Jakarta.

Skousen Smith. 2002. Intermediate Accounting. Erlangga. Jakarta.

Soemita. 2000. Dasar-dasar Akuntansi. BPFE. Yogyakarta. 
Suharsimi Arikunto. 2006. Prosedur Penelitian. Rineka Cipta. Jakarta.

Sukardi. 2003. Metodologi Penelitian Kompetensi dan Praktiknya. Bumi Aksara. Jakarta. S.R. Soemarso. 2004. Akuntansi Suatu Pengantar. Revisi Edisi IV. Rineka Cipta. Jakarta. Warren S.Carl. 2006. Pengantar Akuntansi. Salemba Empat. Jakarta.

Weygandt J. Jerry. 2000. Accounting Principles. Salemba Empat. Jakarta.

Winarno Sigit dan Ismaya Suzana. 2003. Kamus Ekonomi. Bandung. 